\title{
FLOOD RISK, TYPOLOGY, SEVERITY AND MANAGEMENT
}

\author{
Guellouh SAMI* \\ Laboratory LRNAT, University of Batna-2, Algeria, \\ e-mail: guellouhsami@gmail.com \\ Filali ABDELWAHHAB \\ Laboratory LRNAT, University of Batna-2, Algeria, \\ e-mail: abdelwahhabfilali@gmail.com \\ Habibi YAHYAOUI \\ Laboratory LRNAT, University of Batna-2, Algeria, \\ e-mail: y.habibi@univ-batna2.dz \\ Kalla MOUHAMED ISSAM \\ Laboratory LRNAT, University of Batna-2, Algeria, \\ e-mail: kalla.issam@yahoo.fr
}

Citation: Sami, G., Abdelwahhab, F., Yahyaoui, H. \& Mouhamed Issam, K. (2020). Flood Risk, Typology, Severity and Management. Analele Universităţii din Oradea, Seria Geografie, 30(2), 176-181. https://doi.org/10.30892/auog.302107-827

\begin{abstract}
Flooding has now become a major and critical concern in most parts of the world. It is defined as frequent natural phenomena that cause significant and often irreversible human and material damages. The increase in the number of catastrophic floods is first and foremost the consequence of climate change as well as land use that is not in line with environmental reality (construction on floodplain areas, inconsistent development of river beds. This paper represents generalities and definitions which allow an explanation of some fundamental concepts related to flood risk and its management.
\end{abstract}

Key words: damage, flooding, management, risks,

$* \quad * \quad * \quad * \quad * \quad *$

\section{INTRODUCTION}

Natural disasters have always posed serious problems because they affect a large number of people. Floods are among the most significant natural disasters affecting the world (Herman, 2009). Our societies have always been confronted with floods; rivers are both a wealth and a threat to the residents (Bravard and Petit, 1997, p. 213). This duality has long been seen as globally beneficial, but today it seems that this balance has been broken (Kreis, 2004, p. 2). 
Based on information (IDD: International Disaster Database) from the Centre for Research on the Epidemiology of Disasters (CRED, 2007), floods have been at the forefront of natural disaster in the world over the past two decades. Climate change introduces a new variable in the search for sustainable flood risk management (Gralepois and Guevara, 2015, p. 1-20). Taking into account a non-stationary of climatic conditions involves adaptation of flood risk reduction strategies.

Risk is defined as the mathematical expectation of damage to the environment during a reference period in a given region and for a particular hazard (ONU, 1992, p. 98). In a less simplistic way, risk depends on hazard and vulnerability.

Flood risk management is based on prevention, forecasting, protection and crisis management. The evolutions of knowledge and technologies have led to more accurate methods for flood management (Herman, 2010)

\section{METODOLOGY}

This work presents generalities and definitions which allow an explanation of some fundamental concepts related to flood risk and its management. We started with the definition of flood as a combination of hazard and vulnerability. We proceeded to its typology and severity. Finally, we explained its management and its modelling.

\section{THE RISK OF FLOODING}

Natural disasters are divided into six disaster groups: biological, geophysical, meteorological, hydrological, climatological, and extraterrestrial. Floods are in the hydrological group (Yang, 2020, 1-20). Floods encountered around the world are diverse and evolving both in their nature and impact on society (Binns, 2020, p.1-3).

The bibliography offers many definitions of flooding, but they all converge on the following summary: Flooding is a fast or slow, total or partial submersion of an area usually out of water. This submersion can be natural or artificial. Flooding in a broad sense includes river overflows, the rise of water tables, flooding due to failure of protective structures, runoff from heavy thunderstorms and floods resulting from the conjunction of high tides.

The surface water flow is manifesting by stream flooding or outside any organized hydrographic network by the phenomenon of runoff. At the extreme, these phenomena can lead to flooding, flooding by overflow of streams in the first case and flooding by runoff in the second one (Fouchier, 2010, p. 27).

A flood is defined by different criteria such as its genesis, duration, frequency, volume and peak flow (or maximum flow). There is interdependence between the frequency (probability of occurrence) and the magnitude (severity) of this risk, and the floods with rare frequencies are the most severe and catastrophic.

The flood concept is usually defined by different criteria, such as its genesis, duration, frequency, volume and the peak low (or maximum flow). It is also known that there is a clear interdependence between the frequency (probability of occurrence) and the magnitude (severity) of the risk. In another hand, the floods with rare frequencies are the most severe and catastrophic ones.

The centennial or millennium designation characterizes an average probability of occurrence of the flood each year, but does not provide information on the duration between two events. The project flood is a given recurrence flood (depending on the environment and technological requirements) used to calculate dimensions of the hydraulic works and the resistance of the civil works.

\section{Risk: Hazard and vulnerability}

Risk is defined as the combination between hazard and vulnerability. It is thus the combination of the probability of hazard occurrence and the consequences that can result on vulnerable elements in a given environment (Morin, 2008, p. 60). Losses can be estimated in terms of human lives, destruction of infrastructure in financial terms and environmental disorder. 


\section{Risk = hazard $X$ vulnerability}

Hazard is a phenomenon, physical manifestation or activity that could result in loss of life or injury, damage to property, social and economic disruption or environmental degradation (Morin, 2008, p. 60). It is an uncontrollable physical phenomenon of occurrence with random intensities (Lacina, 2012, p. 217). It is defined by a probability that takes into account the occurrence and intensity of the phenomenon with being a function of time and space. A hazard can only cause damage if there are socio-economic and environmental issues exposed to it.

Vulnerability is a propensity to damage or failure of different exposed elements (property, people, activities, functions, systems) of a given territory and society (Leone and Vinet, 2006, p. 925). It is the sensitivity of populations and activities located in an area exposed to a hazard.

The main direct damage caused by flood hazards is damage to people, buildings, socioeconomic activities and the environment. Therefore, risk is necessarily the result of the intersection of two intimately related factors: hazard and vulnerability.

The risk is related to a natural or anthropogenic hazard whose foreseeable effects involves a large number of people, cause significant damages and exceed the response capacities of the directly concerned authorities (Ifen, 2002, p. 4).

For example, flooding does not constitute a risk in an uninhabited area, as no vulnerable element is theoretically present in terms of civil security (Tanguy, 2012, p. 40). If, in another hand, it affects a densely populated area, where important infrastructure is established, the risk will be present and may be important (Cutter et al., 2003, p. 242-261).

Flood risk definition can be considered from hydrological perspectives and geographical points of view. In the first case, emphasis is placed on floodplain areas, identified by hydrological estimates and hydraulic models, where river floods are likely to occur. In the second case, the combination of geographic conditions, environmental and socio-economic factors is used to determine areas with a high probability of damage (Luong, 2012, p. 325).

\section{Typology of the floods}

Flooding encompasses several types of events. The classical typology consists in distinguishing them according to their origin (natural or anthropogenic) and their speed (slow or fast).

Flooding associated with slow plain flooding occurs when rivers leave their minor beds for a long period of time, from a few days to a few weeks, due to heavy rainfall, either due to a rise in their alluvial water table. The kinetics of these floods, which concern large watersheds (more than 1000 $\mathrm{km}^{2}$ ), often make it possible to anticipate them correctly (Fouchier, 2010, p. 27).

Furthermore, torrential floods are characterized by the suddenness of their appearance and their evolution (a few hours) with a rapid response to precipitation. They are caused by intense rainfall over watersheds ranging from tens to hundreds $\mathrm{km}^{2}$.

\section{The severity of the flooding}

Humans live in the world with natural hazards that would seem more and more frequent and intense. In recent years, floods remain the first risk-taking phenomenon of natural origin in the world. They can be a major risk with extremely harmful human and material consequences. They can cause very heavy and irreversible material, human and environmental damage.

Water-related disasters lead the development process to regress for decades. Floods can be one of the factors limiting the development capacity of human society, especially in poor and developing countries where alert capacity and experience of risk management are still limited.

According to the CRED (the Centre for Research on the Epidemiology of Disasters) report, there is an average of 37 catastrophic floods per year worldwide between 1900 and 2013. They account for 34\% of global disasters between 1990 and 2007. Each year, floods affect an average of nearly 31 million people and cause more than 60,000 deaths. The number of people affected by disasters has increased considerably, reaching nearly 200 million in 2007 from 135 million in 2006. 
Of this total, the vast majority (164 million) were affected by flooding. Between 2000 and 2006, an average of 95 million people was affected each year by this hazard.

The consequences are constantly increasing and becoming more and more fatal and increasing with years

The development of rivers that have long been undertaken locally without considering their downstream impact. The removal of flood expansion fields by dams has led to increase flooding in the downstream rivers. To avoid the replication of these errors, development projects must be considered at all watershed area (Kreis, 2004, p. 5).

\section{FLOOD RISK MANAGEMENT}

Flood control is not a new concern, and rivers have long been the focus of work to limit overflows in order to conserve human activities. The hydrological risk represented by floods is the result of the coexistence of this hydrological hazard and societies, which are mostly located near to rivers. Flood risk management is based on crisis prevention, forecasting, protection and management.

Prevention is an aspect of flood management outside of a crisis context. Counter to prevention, forecasting and crisis management correspond to actions in a state of emergency.

The forecast is intended to anticipate the occurrence of a flood and its consequences. Crisis management brings together all the means used to protect, inform and rescue (Hostache, 2006, p. 14).

To manage floods, there is now a greater emphasis on prevention (institutional and legal measures) more than protection (technical measure), which was for a long time dominant and still present (Beucher and Rode, 2009).

The reduction of hydrological risk requires both control of the hazard and mitigation of vulnerability. To protect populations, strategies are often the predetermination of rare floods, referring to the statistical assessment of flows associated with different return periods whose purpose is to implement Flood Risk Protection Plans to regulate urbanization and development in flood-prone areas and anticipate these events and shelter people before and during the flood.

Prevention aims to manage and reduce the risk (hazard and vulnerability) of flooding. On one hand, it includes informing people about the vulnerability to flooding and the steps to follow in the event of a crisis, on the other hand the establishment of protection means and the succor organization (Hostache, 2006, p. 17). It allows choosing a level of protection corresponding to the maximum degree of hazard. This prevention involves structural improvements (dikes, retention basins and dams) and non-structural ones (land use regulations, urban planning constraints). Preventive knowledge of risk can therefore help to lead the political choices of the territory and the protection of socio-economic issues through development (Fouchier, 2010, p. 27).

The forecast aims to anticipate the flood occurrence and its consequences in order to alert the population and put in place more effective succor. Contrary to prevention, forecasting is strongly influenced by time and it is interested to actual or in-formation flooding (Hostache, 2006, p. 17).

Crisis management brings together all the actions that come together during a flood to rescue and protect people and properties.

Hazards that exceed the level of protection determined represent the residual risk (Borrows, 2006, p. 1). This may include, for example, the flood that exceeds the project flood that was used to design a protection structure. The control of this residual risk is then based on monitoring and forecasting systems, alert and crisis management (Fouchier, 2010, p. 27).

\section{FLOOD RISK MODELLING}

This modelling aims to quantitatively measure the risk at any appropriate division of the territory.

\section{Hydrological modelling}

Hydrology encompasses all the processes which lead to the determination of flows in a river, associated with their probability of occurrence. There are two approaches in the hydrology: the deterministic approach and the statistical approach. 
The deterministic approach considers all factors that may influence the watershed response and introduces them into a model for flow estimation.

The statistical approach allows the estimation of flows, of a given probability, from statistical laws that have been adjusted from series of measured flow data (Blin, 2001, p. 8-9).

\section{Hydraulic modelling}

A flood is a very complex natural phenomenon, whose analysis requires efficient and elaborate tools, for example hydraulic models. The main purpose of hydraulic models is to simulate hypothetical or real floods numerically, which makes it possible to characterize the hazards in space and time (water levels, flow rates, times of submersion, etc.).

Hydraulics refers to applications, calculations and treatments which allow water levels to be obtained from flow rates calculated at the scale of watercourse section.

Therefore, hydrology is the discipline which allows getting the flows and their return periods. Hydraulics is the discipline that makes it possible to obtain the water levels and the speeds corresponding to these flows.

\section{Geographic information systems (GIS)}

GIS are spatial analysis tools based on the overlay of qualitative and quantitative data, all georeferenced in the same projection system (Grivel, 2008, p. 517). GIS manipulates geographic information that refers to geodesy, global positioning (GPS), remote sensing and spatial reference databases related to environmental characteristics. A geographic information system has become an essential tool in flood diagnosis. It offers unprecedented flood extension mapping and being a valuable source of information in the preparation of Flood Risk Prevention Plans.

\section{CONCLUSION}

Flooding is one of the main natural hazards in the world; this unpredictable and recurring phenomenon is aggravated by intense human activities and a poorly organized space. The damage occurs when land cover in a flood-prone area is not suitable for flooding. For this reason, flooding in sparsely populated areas or in areas where urbanization is particularly well adapted to flooding results in little damage.

In the end, effective flood risk management must be based on three essential concepts: prevention, forecasting, protection and crisis management.

\section{REFERENCES}

Beucher, S., \& Rode, S. (2009). L'aménagement des territoires face au risque d'inondation: regards croisés sur la Loire moyenne et le Val-de-Marne. M@ ppemonde (En ligne), (94), 1-19.

Binns, A. D. (2020). Flood mitigation measures in an era of evolving flood risk. https://doi.org/10.1111/jfr3.12659

Blin, P. (2001). Développement d'une nouvelle méthode de cartographie du Risque unitaire d'inondation (crue) pour des résidences. Mémoire de Maître ès sciences (M. Sc.) Université du Québec. INRS-EAU, pp 8-9.

Borrows, P. (2006). Living with flooding-Noah's legacy. Irrigation and Drainage. The journal of the International Commission on Irrigation and Drainage, 55(S1), S133-S140.

Bravard, J.P., \& Petit, F. (1997). Les cours d'eau. Dynamique du système fluvial, Armand Colin, Paris.

CRED (2007). Bilan des catastrophes naturelles dans le monde de 1975 à 2004, The OFDA/CRED International Disaster Database, Université Catholique de Louvain, Bruxelles, Belgique.

Cutter, S. L., Boruff, B. J., \& Shirley, W. L. (2003). Social vulnerability to environmental hazards. Social science quarterly, 84(2), 242-261.

Fouchier, C. (2010). Développement d'une méthodologie pour la connaissance régionale des crues (Doctoral dissertation, Doctorat Université Montpellier II).

Gralepois, M., \& Guevara, S. (2015). L'adaptation aux risques d'inondation façonnée par les métiers de la ville. Tensions à l'échelle du projet d'aménagement. Développement durable et territoires. Économie, géographie, politique, droit, sociologie, 6(3), 11014.

Grivel, S. (2008). La Loire des îles, du Bec d'Allier à Gien : rythmes d'évolution et enjeux de gestion [Ressource électronique] sous la direction de E. Costard-Gautier. Université Paris VIII Vincennes-Saint Denis, pp. 517. 
Herman, G. V. (2010). Using Geographical Information (GIS) System for Management of Flood Risks in the Somes Plain. In Cross-Border Partnership with Special Regard to the Hungarian - Romanian - Ukrainian Tripartite Border, Book Editors Ioan Horga, Istvan Suli Zakar, Publishing House University of Debrecen Press, p. 175 -179.

Herman, G.V. (2009). Omul şi modificările antropice din Câmpia Someşului [The man and anthropogenic changes in Somes Plain]. Editura Universității din Oradea, p. 227 p., ISBN 978-973-759-981-0, Oradea.

Hostache, R. (2006). Analyse d'images satellitaires d'inondations pour la caractérisation tridimensionnelle de l'aléa et l'aide à la modélisation hydraulique. Thèse de Doctorat, spécialité Sciences de l'eau, UMR Territoires, Environnement, Télédétection et Information Spatiale, Cemagref /ENGREF/CIRAD, Montpellier, France, pp. 14.

IFEN (2002). Catastrophes naturelles et plans de prévention des risques. Les données de l'environnement, $\mathrm{n}^{\circ} 73, \mathrm{pp} 4$.

Kreis, N. (2004). Modélisation des crues des rivières de moyenne montagne pour la gestion intégrée du risque d'inondation application a la vallée de la Thur (Haut-Rhin). Thèse de doctorat à l'Ecole Nationale du Génie de l'Eau et de l'Environnement de Strasbourg, pp 5.

Lacina, T. (2012). Analyse des refoulements dans les réseaux de drainage urbain [enligne]. Mémoire présenté à l'Ecole de Technologie Supérieure, l’Université du Québec, pp 217.

Leone, F., \& Vinet, F. (2006). La vulnérabilité, un concept fondamental au cœur des méthodes d'évaluation des risques naturels. la "Vulnérabilité des sociétés et territoires face aux menaces naturelles», Ouvrage collectif sous la direction de Leone F. et Vinet F., Géorisques, 4.

Luong, A. T. (2012). Évaluation des risques d'inondations dans le bassin du fleuve Huong, province de Thua Thien Hue, centre du Vietnam (Doctoral dissertation, Université du Québec à Montréal).

Morin, M. (2008). Concepts de base en sécurité civile, pp 60.

O.N.U./DAH. (1992). Glossaire international multilingue agréé de termes relatifs à la gestion des catastrophes, http://www.unisdr.org/unisdr/glossaire.html, pp 98.

Tanguy, M. (2012). Cartographie du risque d'inondation en milieu urbain adaptée à la gestion de crise analyse préliminaire. Dans le cadre de son examen doctoral pour l'obtention du doctorat en Sciences de l'eau. Institut national de la recherche scientifique Centre Eau Terre Environnement 490, rue de la Couronne Québec (Québec) G1K 9A9. pp 40.

Yang, T. H., \& Liu, W. C. (2020). A general overview of the risk-reduction strategies for floods and droughts. Sustainability, 12(7), 2687.

Submitted:

Octomber 10, 2019
Revised:

July 07, 2020
Accepted and published online December 02, 2020 